\title{
THE MATING OF DIACAMMA ${ }^{1}$
}

\section{By W. M. Wheeler and J. W. Chapman.}

Diacamma is a very clearly defined genus of Ponerine ants confined to India, Ceylon, Southern China, the Malay Archipelago, New Guinea and the northeast corner of Australia. The species were carefully monographed by Emery in 1897, and a list of those known in 1911 was published by the same author in the "Genera Insectorum". There are only thirteen species, but one of them, the Indomalayan rugosum has some 25 subspecies and varieties. All the species have large black or bronzy, more rarely beautifully metallic blue or green, workers (Fig. 1), and pale yellow or yellowish red males (Fig.2), with very long antennæ and the pygidium terminating in a curved spine.

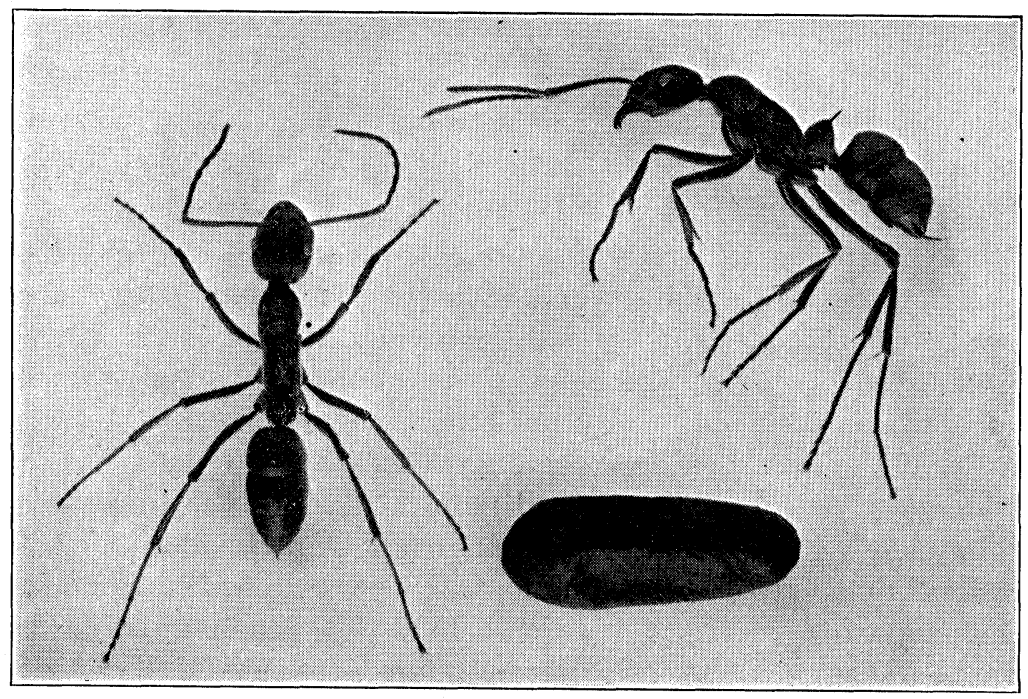

Fig. 1. Worker of Diacamma australe, dorsal and lateral view and black cocoon of same $\mathbf{x}$.

1Contribution from the Entomological Laboratory of the Bussey Institution, Harvard University, No. 212. 


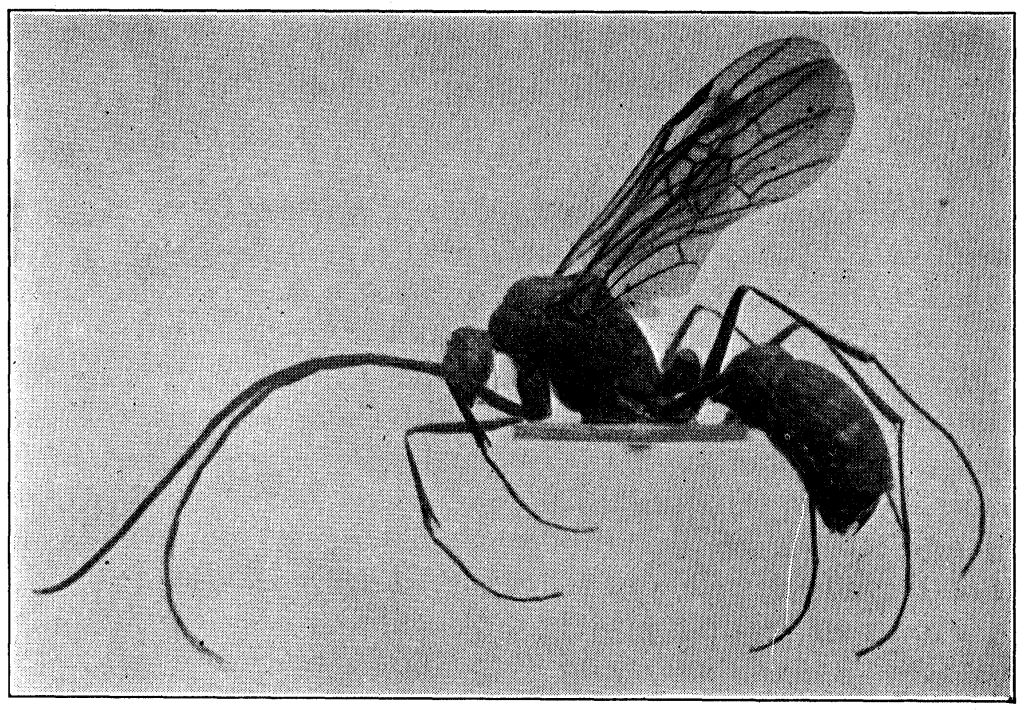

Fig. 2. Male of Diacamma australe x5.

The workers are very agile and graceful in their movements and both Rothney (1889) and Bingham (1903) regard them as by far the most intelligent of Oriental ants.

The species of Diacamma are also of unusual interest from the fact that although several of them are common and have often been observed in the field, no one has ever been able to find in any one of them a form corresponding to the winged, fertile female, or queen of other ants. Frederick Smith (1863), nearly 60 years ago, described a worker and "female" of $D$. rugosum subsp. tortuolosum and remarked that "the sexes were identified by Mr. Wallace", but there can be little doubt that he had before him a female belonging to some very different Ponerine genus, possibly Bothroponera. In $1899 \mathrm{Col}$. Bingham remarked that "Diacamma $\%$ has been for years a desideratum of Myrmecologists", and he adds: "It makes me feel sad to think of the many nests I have ruined, the hours of hard labour I have spent, and the language $I$ have used in the futile search for o Diacamma". He then describes two specimens which he found escaping from 
a nest of $D$. rugosum subsp. vagans var. indicum and took to be queens; but in 1903 he was compelled to admit that what he had seen was "only a large male." The perusal of his description, however, shows that he could not have seen even males of Diacamma, for they were colored like the worker and sculptured, whereas the male of vagans, of which we have numerous specimens, is smooth and yellow. There can be no doubt that he saw males of a very different Ponerine ant, namely Odontoponera transversa Smith, and that he must have been mistaken in regard to their belonging with the vagans workers among which he found them.

These failures led Emery (1911, p. 64 nota) to conclude that "we must suppose that the female Diacamma resembles the worker so closely as to be confused with it." In 1914 the senior author studied D. australe at Cairns and Kuranda in Northern Queensland and, after alluding to the failure of previous observers to find the missing phase, made the following statement (1915b, p. 335): "In excavating the nests of australe, therefore, I scrutinized the ants very closely in the hope of finding the unknown female, but in vain. Though I searched dozens of nests, I saw nothing resembling a winged female or even a worker with conspicuously enlarged gaster. I found plenty of larvæ and pupæ and in some of the nests during late October a number of males. These are bright reddish yellow, with conspicuously long antennæ and quite unlike the bronzy black workers. As I failed to find any differentiated queen and as all the pupæ were of the same size, I feel confident that in Diacamma the egg-laying function must be usurped by one or more fertile workers during the breeding season."

That the assumptions of Emery and the senior author were well founded has now been demonstrated by the junior author's observations on $D$. rugosum subsp. geometricum Smith in the Phillippines. During a sojourn of six years at Dumaguete in Negros Oriental he found D. geometricum to be a common ant from sea-level to about $3000 \mathrm{ft}$., living in open "cogon" or shrubby places along the edges of forests, where the vegetation is only three or four meters high. Here it nests under the bark of 
old logs or dead, standing tree-trunks and fills any chinks or openings with vegetable detritus. ${ }^{1}$ The colonies are small, comprising, when fully developed, scarcely more than 50 workers and a dozen males. The workers are rather circumspect and cowardly and the males tend to fly out of the nest as soon as it is opened. The latter, like the males of Leptogenys and the Dorylines, are frequently taken at lights. On April 14, 1922 a nest of geometricum, situated under the loose bark of a large knot at the base of a standing tree trunk, was investigated and found to contain an average colony of workers with some eight males, a number of young and full grown larvæ and a few cocoons, which, as the senior author has shown (1915b) for this and other species of the genus, are dark brown or black. One of the male was copulating with a worker and as the pair failed to separate even after preservation in alcohol, we have been able to secure the accompanying photograph and drawing (Figs. $3 \& 4$ ). The fact that the wings of the male had been gnawed away at their

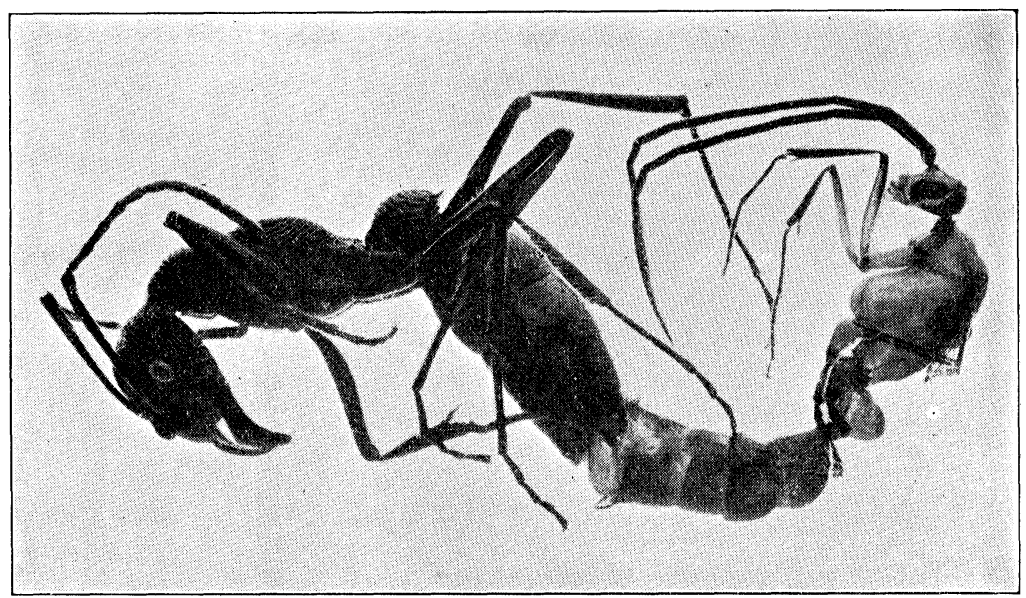

Fig. 3. Fertile worker and male of Diacamma rugosum geometricum in copula, from the left side $x$.5.

1 Nearly all the nests contain a number of small cylindrical vegetable bodies, which prove to be the joints of the flower panicle of a peculiar grass (Rottboellia).' These joints, each of which contains a seed, are scattered by the plant, collected by the ants and stored in their nests. It would seem, therefore, that D. geometricum is to some extent vegetarian. 


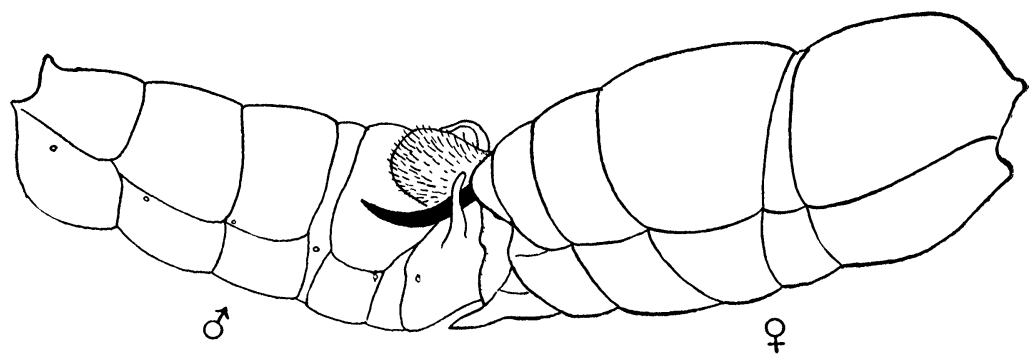

Fig. 4. Gasters of worker and male Diacamma rugosum geometricum from the right side $\mathbf{x} 7$.

bases suggests that the workers may thus prevent the escape of members of the opposite sex from the nest. The same mutilation is also practised on the males of Eciton, as noticed by W. Müller (1886) and the senior author (1921, p. 312). And since the other males taken in the same Diacamma nest were not deälated, it would seem that the workers do not mate with the males of their own colony, that is with their sons or brothers (adelphogamy), but with males that have come from other colonies. The very long sensitive antennæ of these insects, so like those of the Ichneumons, may enable them the more easily to seek out alien colonies of their own species. The small size of the Diacamma colony, moreover, indicates that only a single worker is fecundated and assumes the role of a queen, for if several or all of the workers laid fertilized eggs the colonies should be much more populous.

Externally the worker found in copula differs neither in size nor in structure from any of her sisters. Examination of the materials in the senior author's collection shows that both in rugosum and its varieties and in the various other species of the genus all the workers taken from the same colony are singularly uniform in size and structure, even to the minute details of sculpture and pilosity. As will be seen from Fig. 4, which shows the gasters of the mating individuals from the right side, the male and female genital orifices are in broad and very intimate contact. The powerful sting of the female is extruded and is held down by the finger-shaped process of the right external genital valve of the male. 
Dissection of a number of Diacamma workers and especially of the mating worker supports the inference that only one individual in a colony assumes the reproductive function at a time. Unfortunately the material had been in rather weak alcohol for several months and the very hard chitinous integument of the gaster had prevented penetration, so that the internal organs were considerably decomposed. In many of the workers, of which more than 20, belonging to three colonies, were dissected, no ovaries could be detected. In one, however, two ovarioles were clearly seen, each of the type figured by Miss Holliday (1903, Fig.Ab, p. 295) for the ergatoid queen of Lobopelta elongata,i.e. with a large number of very small ova separated by clusters of nurse-cells. Such undeveloped ovaries were probably present in all the specimens but could not be detected on account of defective preservation. This may also explain our inability to find a spermatheca in any of these individuals. Fortunately the mating worker was in a somewhat better state of preservation. The ovaries were found very far forward, in the large first gastric segment and applied to the sides of the crop. There were five ovarioles in each ovary and the lowermost egg in each ovariole was fully developed and of an elongate-oblong shape, as in some other Ponerinæ (Pachycondyla, Lobopelta). The vagina and a large spermatheca attached to its dorsal wall were filled almost to bursting with compact masses of spermatozoa.

For some time evidence has been accumulating to show that Diacamma is not the only ant genus in which the winged qucen has been lost and her function in the colony usurped by a fertile worker. The senior author, in the paper above mentioned (1915b, p. 337), called attention to the fact that winged females do not exist in the Ponerine genus Rhytidoponera, which is represented by a number of species in the Australian and Papuan Regions. The same condition very probably obtains also in the South African Streblognathus and Ophthalmopone and in the Neotropical Dinoponera, all genera belonging to the same subtribe as Diacamma (Pachycondylini). He also stated in his monograph of the Australian honey-ants of the Dolichoderine genus Leptomyrmex (1915a,p. 260) that true queens are in all probability absent 
in this genus and "that there are in each colony one or more fertile workers which supply the eggs that delevop into workers and males." And Arnold (1916, p. 195) says of a species of the South African genus Ocymyrmex, which belongs to the subfamily Myrmicinæ: "I have frequently dug up the nests of the variety arnoldi [of O.weitzaeckeri Emery] without ever having found a female of any sort, nor have females of any species been described up to now. I believe that the genus will be found to have only ergatoid queens, or that the egg-laying function (with the production of males and females) is possessed by the whole worker caste."

The fertile workers of Diacamma which function as queens are obviously not to be confused with two other types of wingless females, the ergatoid, or ergatomorphic queens and the dichthadiigynes. ${ }^{1}$ Ergatoid queens are of rather frequent occurrence, either as the only form of fertile female or coexisting in the same species with winged queens, in one genus of Pseudomyrminæ (Viticicola), in at least one genus of Formicinæ (Polyergus), in several Myrmicine genera (Monomorium, Myrmecina, Leptothorax, Crematogaster, Harpagoxenus, etc.) and especially among the Ponerinæ (Eusphinctus, Cerapachys, Acanthostichus, Acanthoponera, Paranomopone, Alfaria, Megaponera, Ponera,Onychomyrmex, Leptogenys, Anochetus and Champsomyrmex).

In some cases (Leptogenys, Paranomopone, Megaponera and Eusphinctus) the queens differ very little from the workers, except in having traces of ocelli, a somewhat thinner petiole or a larger abdomen; in others the thorax is more complicated in structure and approaches that of the winged queen, while in still others (Acanthostichus, Onychomyrmex, Nothosphinctus) there is an approach to the dichthadiigyne, which is the only queen in all the genera of Dorylinæ, a characteristic form with very simple thorax, without eyes or with minute vestiges of eyes and ocelli and with a huge abdomen. Most of the ergatoid forms may be derived from the typical winged queen through a loss of the wings and a progressive, degenerative simplification of other characters,

\footnotetext{
$1 \mathrm{~A}$ fourth form of female, the pseunogyne, is not discussed because it is pathological and does not function as a reproductive caste.
} 
but it is conceivable that the dichthadiigynes may have arisen from fertile workers like those of Diacamma after complete phylogenetic suppression of the winged queen. The latter supposition will have to be tested by thorough morphological study of all the available fertile female forms.

The conditions in Diacamma are suggestive also from another point of view. It has long been known that well-fed worker ants may lay eggs, but no one has ever seen a male copulating with a worker, and only Reichenbach, Mrs. Comstock and Crawley have found that eggs laid by workers may develop into workers. All other authors (Miss Fielde, Janet, etc.) maintain that such eggs invariably produce males. In Diacamma geometricum we actually have an ant whose workers copulate with the males and must therefore produce worker as well as male offspring, since there is no morphologically differentiated queen. Further studies of tropical ants in the field will probably compel us to to abandon certain other generalizations which we have reached from a too exclusive study of temperate European and North American species confined in artificial nests.

\section{BiBLIOGRAPHY.}

1916. Arnold, G. A Monograph of the Formicidæ of South Africa (Myrmicinæ). Ann. South Afric. Mus. 14, 1916, pp. 159-270, 3 pls.

1899. Bingham, C. T. Note on Diacamma, a Ponerine Genus of Ants, and of the finding of a female of D. vagans Smith. Journ. Bombay Nat. Hist. Soc. 12, 1899, pp. 756, 757.

1903. _ _ _ _ _ The Fauna of British India including Ceylon and Burma. Hymenoptera, Vol. 2. London, Taylor \& Francis, 1903.

1897. Emery, C. Revisione del Genere Diacamma Mayr. Rend. Sess. R. Accad. Sc. Ist. Bologna, 1897. pp. 147-167, 1 pl.

1911 Genera Intsectorum. Family

Formicidæ, Subfamily Ponerinæ. Fasc. 118, 1911, pp. $1-125,3$ pls.

1903. Holliday, M. A study of Some Ergatogynic Ants. Zool. Jahrb. Abth. Syst. 19, 1903, pp. 293-328, 16 figs. 
1886. Müller, W. Beobachtungen an Wanderameisen(Eciton hamatum). Kosmos 1, 1886, pp. 81-93, 1 fig.

1889. Rothney, G. A. J. Notes on Indian Ants. Trans, Ent. Soc. London, 1889, pp. 347-374.

1863. Smith, F. Catalogue of the Hymenopterous Insects collected by Mr. A. R. Wallace in the Islands of Mysol, Ceram, Waigiou, Bouru and Timor. Journ. Proc. Linn. Soc. London. Zool. 7, 1863, pp. 6-48.

1915a. Wheeler, W. M. The Australian Honey-ants of the Genus Leptomyrmex Mayr. Proc. Amer. Acad. Arts Sc. 51, 1915, pp. 255-286, 12 figs.

1915b. —__ On the Presence and Absence of Cocoons Among Ants, the Nest-spinning Habits of the Larvæ and the Significance of the Black Cocoons among Certain Australian Species. Ann. Ent. Soc. Amer. 8, 1915, pp. 323-342, 5 figs.

1915c. —_ _ Paranomopone, a New Genus of Ponerine Ants from Queensland. Psyche, 22, 1915, pp. 117-120, $1 \mathrm{pl}$.

1916. ——_ The Australian Ants of the Genus Onychomyrmex. Bull. Mus. Comp. Zool. 9, 1916, pp. $45-54,2$ pls.

1918 The Australian Ants of the Ponerine Tribe Cerapachyini. Proc. Amer. Acad. Arts Sc. 53, 1918, pp. 215-265, 17 figs.

1921. _ _ _ Observations on Army Ants in British Guiana. Proc. Amer. Acad. Arts Sc. 56, 1921, pp. 291-328, 10 figs. 

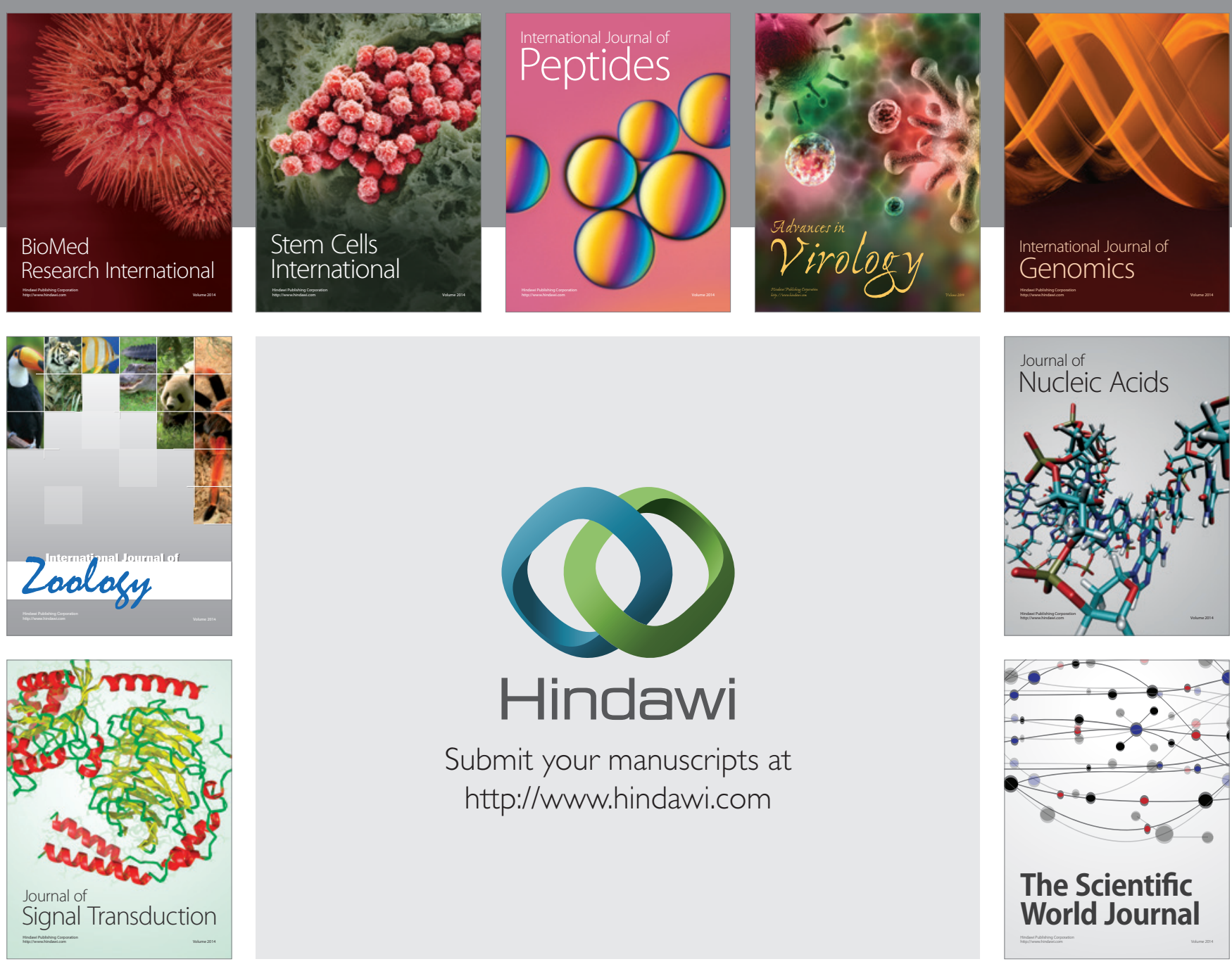

Submit your manuscripts at

http://www.hindawi.com
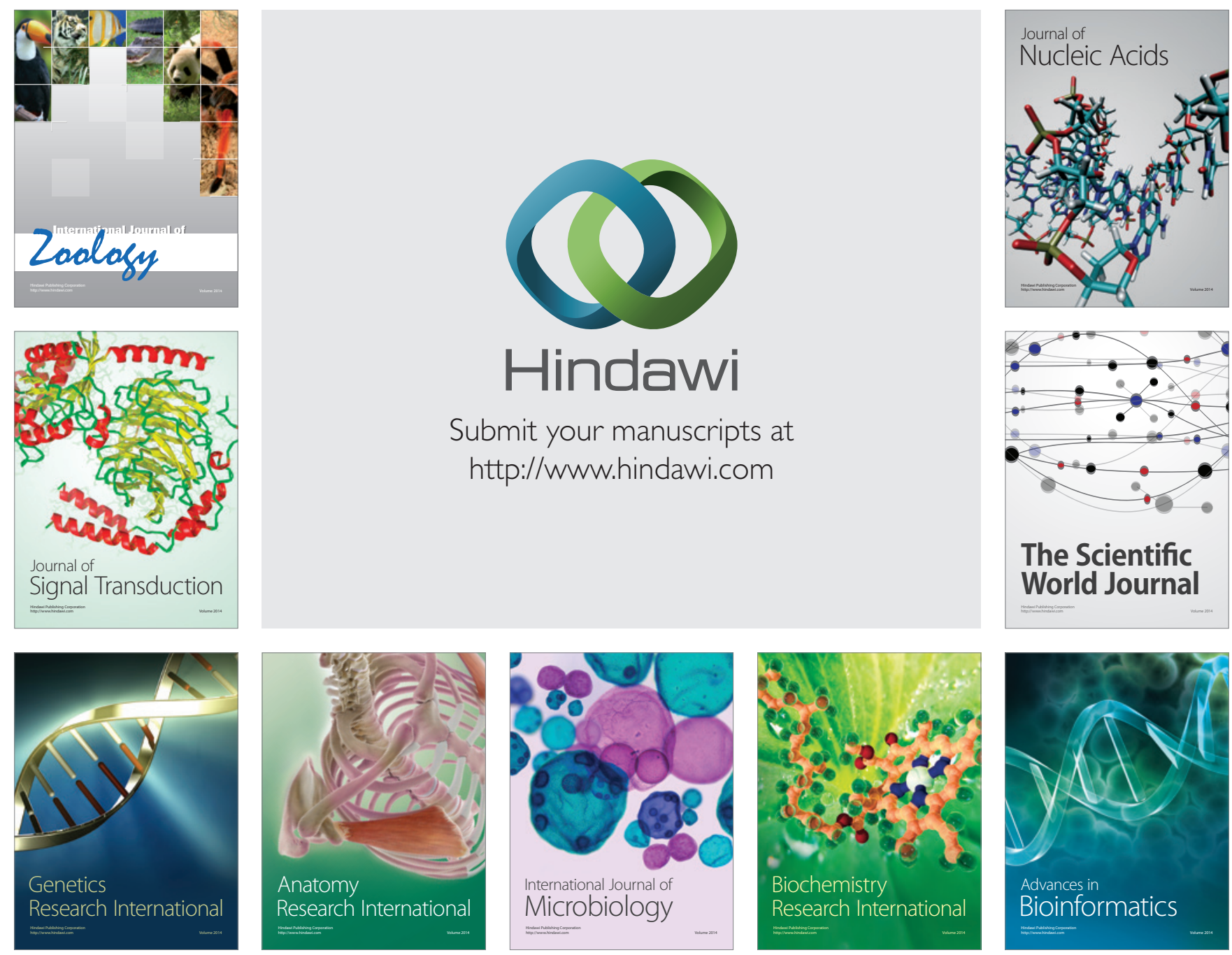

The Scientific World Journal
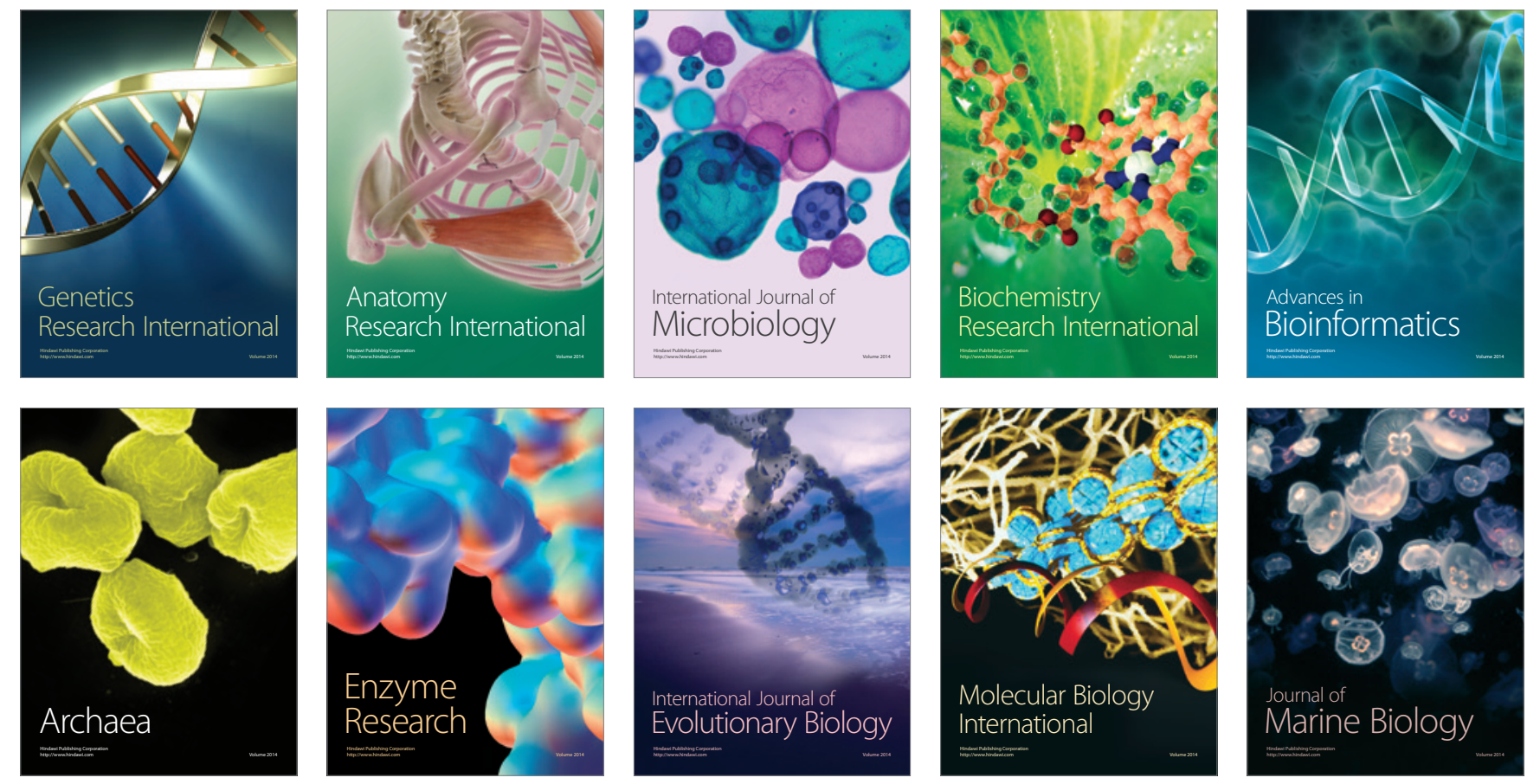